\title{
Shadowing: Interprofessional Learning
}

Journal of Research in Interprofessional

Practice and

Education

Vol. 5.2

November 2015
Journal of Research in Interprofessional Practice and Education (JRIPE)

Vol. 5.2

(C) 2015

Corresponding author: Frøydis Vasset.

Email: fv@hials.no

\author{
Frøydis Perny Vasset, PhD, \& Synnøve Hofseth Almås, PhD
}

\begin{abstract}
Background: The Norwegian government has indicated that health and social studies should emphasize interprofessional collaborative learning (IPL), especially in clinical placements. Through IPL, students have the opportunity to gain insight into other professional responsibilities and minimize negative stereotypes. This might improve collaboration across professional boundaries. Professionals with collaborative competence might solve complex health problems, and thus improve the quality of healthcare. The objectives of this article are to investigate the IPL experiences nursing students acquire through shadowing practice with different professionals in home care.
\end{abstract}

Methods and Findings: To develop a model for IPL, 12 nursing students spent five days shadowing four different healthcare professionals working in home care. At the end of the pedagogical intervention, the students reflected on the practice and the role of the different professionals they had followed. To investigate how the students experienced interprofessional shadowing practice, the reflective notes were analyzed, templates for the selected professionals were drawn up, and four focus group interviews were conducted The results showed that students had acquired knowledge of other professions' responsibilities and were aware of the need for an interprofessional approach to home care.

Conclusions: This kind of shadowing might be an ideal model for educational institutions seeking to implement IPL.

Keywords: IPL; Shadowing; Interprofessional learning; Home care; Placement; Nursing students

\section{Introduction}

Collaborative practice has been highlighted as necessary to resolve compounding health problems in a complex municipality. A 2005 report by the Norwegian Social and Health Directorate states that health and social care should be seamlessly coordinated and integrated. Complex challenges are a natural part of home care. Home care is the provision of nursing care to acutely and chronically ill people, of different ages, in their homes. There is a focus on environmental, psychosocial, economic, cultural, and personal factors that influence the individual patient and their family health status [1]. 
2

Shadowing: Interprofessional Learning

Vasset \& Almås

Journal of Research in Interprofessional Practice and Education

Vol. 5.2 November 2015
Home care is the largest segment of health and social care services within the municipality, and the intention is that everyone should be able to remain in their own residence for life [2]. Norway's "Coordination Reform" [3] also underlines collaboration across sectors, agencies, and professional boundaries, as well as integrated interaction, as necessary components of comprehensive health and social care, creating a holistic view of patient care [4]. Users of home care can easily experience adverse complications resulting from misunderstandings and problems connected to the interaction between professionals. This applies particularly to those with complex disorders.

As the White Paper Education for Welfare: Interaction as Key [5] by the Norwegian Ministry of Education and Research indicates, facilitating collaborative practice requires changes in the curricula for health and social studies. Educational programs should place more emphasis on IPL in the curricula. Although the White Paper does not specify the best way to implement this, it is underlined that students should learn together across programs, and that IPL should contain elements of a common practice. This implies that health and social care educations should introduce IPL as an element of clinical placements.

To initiate IPL, the Norwegian government has introduced common, general content in curricula for all health and social programs [6]. Research shows that the introduction of credits was not sufficient to change students' attitude toward interprofessionalism [7]. The Centre for the Advancement of Interprofessional Education (CAIPE) [8] defines IPL as when "two or more professions learn with, from, and about each other to improve collaboration and the quality of care." A challenge is to implement IPL in educational institutions with limited health and social programs.

One question that arises is which educational models are best suited to developing students' competence for collaborative practice, which in turn can improve the quality of health and social care. This study seeks to examine the experiences of nursing students during one week of interprofessional shadowing in municipal health and social services. The question of interest focused on what IPL the nursing students experienced through shadowing professionals in home and social care.

\section{Interprofessional collaboration as an educational approach}

Through IPL, students have the opportunity to become acquainted with and gain respect for different professionals, and minimize bias and stereotypes [9]. This might improve the collaborative competence of health and social professionals. Collaboration is not learned through theory alone [10], but through experiences with patients and collaboration with other professionals working in health and social care. The experience of IPL can be campus based and/or placement based. While IPL at educational institutions can lead to a more limited understanding of collaboration, practice-based initiatives [11] provide more occasions for interaction [12]. This may provide different but complementary opportunities for IPL.

\section{Shadowing practice as pedagogical method}

The challenges for educational institutions in facilitating IPL are many and complex. At educational institutions where more professions are taught, there are more oppor- 
3

Shadowing: Interprofessional Learning

Vasset \& Almås
Journal of Research in Interprofessional Practice and Education

Vol. 5.2 November 2015 tunities to implement IPL. This is difficult at educational institutions where there are few health and social programs, as the intention is that students should learn with, about, and from each other. Therefore, IPL will probably perform best in educational institutions with many health and social programs.

Students construct their own learning within social frameworks. Learning is a process in which knowledge is formed through the transformation of experience, and includes four stages [13]. First, students experience a given situation. Next, students reflect on their experiences and what they mean. Based on reflective observation, students structure and generalize experiences or formalize the learning outcomes of their experiences. Later this knowledge will be tested in new contexts. By shadowing other health and social care professionals, the students might acquire knowledge about other professionals' competence. This might increase students' respect for different professionals, and facilitate collaborative practice.

During the process of shadowing, as part of IPL, students can observe, first-hand, the work environment, employment reality, and occupational skills [14] of a specific profession. Observation as a learning method comprises three steps: preparation before the event, active observation, and reflecting afterward [15]. IPL implies learning, and learning requires reflection. Reflection on concrete situations can be seen as a basic methodological approach to learning, with the purpose of developing practical professional knowledge [16,17], such as in the nursing profession. Most models of reflection include critical reflection on actual experience and practice. The students are then encouragd to share their experiences, reflect on what they learned, evaluate what they learned, and discuss how they plan to use the knowledge they obtained $[18,19]$. The students would also be able to identify further learning needs [19].

Students acquire an understanding of how the health and social professions have different but complementary approaches to patient care [14]. Studies show that students' motivation for interprofessional interaction seems to be reinforced by IPL in shadowing practices $[14,15,20]$.

\section{Model of interprofessional shadowing practice}

The intention of this study was to investigate how nursing students experience a week of interprofessional shadowing practice as part of their placement in home care. A similar model of IPL was piloted in North England. The overall aim in the North England was to develop, implement, and embed interprofessional, work-based practice placements that promote collaborative learning [21].

\section{Method}

\section{Participants}

In the middle of the placement period, 12 nursing students in their second cohort shadowed different health and social professionals during their work in home care. Students chose four different relevant professionals, contacted them, and arranged a time to shadow them at work for one day. The professionals were physiotherapists (PT), occupational therapists (OT), biomedical laboratory scientists ${ }^{1}$ (BMLS), and social educators 
4

Shadowing: Interprofessional Learning

Vasset \& Almås

(SE). The study includes two periods in the spring and two periods in the autumn. This municipality in the west coast of Norway was chosen for practical reasons.

\section{Curriculum}

As Figure 1 shows, the project had a preliminary component, an execution component, and a reflective evaluation. The students had a lesson about IPL in school, both in their first cohort and as a reflection day in their second cohort. They had, in advance, viewed a PowerPoint presentation that showed different aspects of collaborative practice, and they also had access to literature on collaborative practice. During this shadowing practice the students described, in a template, the characteristics of the various professional practitioners.

At the end of the week the students participated in a reflection group where they, together with supervisors and researchers, reviewed the completed template and discussed what characterized the professions they followed. The reflective note concerned the challenges of improving collaboration between different professions. The focus was on the students' experience and their learning with, from, and about other professionals, the students' knowledge of others' work roles and responsibilities, and, last but not least, collaboration strategies. A short film that presented a lack of collaborative practice at a doctor's office was shown. The students discussed the events in the film, and reflected on various ways to promote collaboration between different professionals and how to include the patient/client in the process.

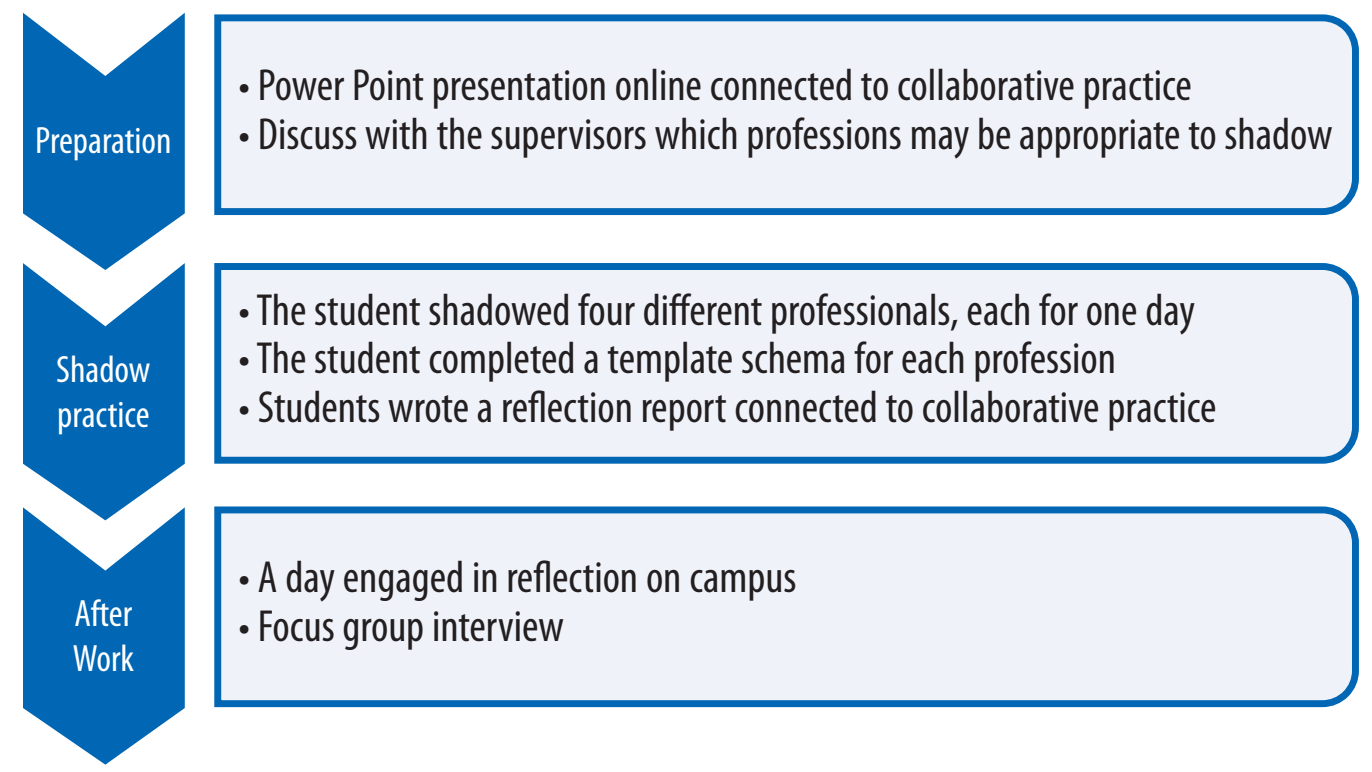

Figure 1. Model of interprofessional shadowing practice

Journal of Research in Interprofessional Practice and Education

Vol. 5.2

November 2015

\section{Assessment methods}

At the end of the IPL week, focus group interviews were conducted to investigate students' experience. The template and the reflective notes were handed over to researchers.

In this study, qualitative methods were chosen to gain insight into how nursing students experienced interprofessional shadowing practice. Such an approach can provide 
Vasset \& Almås

Journal of Research in Interprofessional Practice and Education

Vol. 5.2 November 2015

\section{Journal of Research in Interprofessional Practice and Education}

comprehensive and complementary data [22,23]. We assume that, in a study with few participants, the mutual influence of different methods will enhance the data. Researchers indicate that the great strength of using several methods is that the findings from the two methods confirm their validity [23,24]. Cooper and her colleagues [25] highlight the need to use several methods to evaluate both the outcome and the process.

\section{Data materials}

The data material consisted of the submitted templates, reflective notes on collaborative practice, and focus group interviews. The template was developed at the Institute of Interprofessional Health Sciences Education at McMaster University in Canada [26].

Students were asked to answer the following questions:

- What are the roles/responsibilities of this profession?

- What are the unique features of this profession?

- What else is useful to know about this profession?

Nilsen and Røysing developed a reflective note at Østfold University College in Norway and gave their permission to use it for this study. The work requirements were that students should submit a reflective note that involved collaborative practice and a template [27].

Focus group interviews can be characterized by the interaction between interviewees. Rarely is the interaction/reflection in an interview as focused on a theme as in a focus group interview [28]. It is a research method in which data (or a theme) is produced through interaction in a group [28]. On the last day of the week focus group interviews with the students were conducted. Four interviews were carried out, and the interviews lasted about 30 minutes each and were audiotaped and transcribed.

\section{Textual analysis of the template, reflective note, and transcribed focus group interviews}

Lindgren [29] indicates that language always involves some form of categorization. Some events are characterized as "good," others as "bad." The basic idea of social science text analysis is that all significant activities are regulated simultaneously by linguistic and social structures. Whenever something is said, written, or expressed, it happens in a context that is created by socio-cultural rules [29]. Textual analysis is about bringing together the text and the context. Shapiro and Markoff [quoted in 29] define textual analysis as a systematic reduction of text to a set of themes that illustrates the various aspects of the text. In step one of the assessment of this study, the authors read the template, reflective notes, and transcribed focus group interviews to gain an impression of central traits in the material. In step two, the authors read the data thoroughly, and statements that seem to describe the research area were underlined. In the third step, the topics were abstracted to make new categories [30].

\section{Results}

This study looks at nursing students' experiences of shadowing IPL in home care for a week. The results are visible in the templates, reflective notes, and focus group inter- 


\section{JRIPE}

6

Shadowing: Interprofessional Learning

Vasset \& Almås

views. The students' perceptions of the core competencies of different health and social care professionals are analyzed in Table 1. In the reflective notes and in the focus group interviews, the students' evaluations of IPL emerged. This was analyzed and is presented in Tables 2 and 3.

\section{Templates}

The results from the templates show that the students gained insight into the core competencies of the different professionals.

\section{Table 1. Template schema}

\begin{tabular}{|c|c|c|}
\hline Profession & Core competence & Students' statements \\
\hline \multirow[t]{2}{*}{$\begin{array}{l}\text { Occupational } \\
\text { therapist }\end{array}$} & Habilitation & $\begin{array}{l}\text { An 0T facilitates environments/daily activities, and an 0T makes patients } \\
\text { self-reliant. The 0T focuses on movement ability and promotes activities } \\
\text { for patients. An 0T arranges the simplest possible days for the patients. } \\
\text { The 0T's function is to promote health through activity and participation. }\end{array}$ \\
\hline & Ergonomics & $\begin{array}{l}\text { The 0T was responsible for planning and organizing guided tours for } \\
\text { patients, and the 0T was responsible for getting stair lifts installed in } \\
\text { the patient's house. The 0T works in a nearby environment so they do } \\
\text { not hinder activity and participation. They are working on designing } \\
\text { public spaces so that public transport, outdoor areas, and so on, are } \\
\text { designed so all people can be as self-reliant as possible. }\end{array}$ \\
\hline \multirow[t]{2}{*}{ Physiotherapist } & $\begin{array}{l}\text { Rehabilitation/ } \\
\text { habilitation }\end{array}$ & $\begin{array}{l}\text { A PT works with rehabilitation, treatment, and enhancing training, and } \\
\text { endurance. I believe that this professional group ensures that patients } \\
\text { will use their own resources. }\end{array}$ \\
\hline & Preventive work & $\begin{array}{l}\text { The PT promotes health, prevents injury, identifies needs, provides } \\
\text { advice and guidance, and this is aimed at individuals and groups. }\end{array}$ \\
\hline \multirow{2}{*}{$\begin{array}{l}\text { Biomedical } \\
\text { laboratory } \\
\text { scientist }\end{array}$} & Procedure & $\begin{array}{l}\text { Procedure and analysis are key areas of a biomedical laboratory } \\
\text { scientist's (BMLS) work. }\end{array}$ \\
\hline & Analysis & $\begin{array}{l}\text { A BMLS performs analysis of biological materials using advanced } \\
\text { technological equipment, and is responsible for all the equipment one } \\
\text { needs for a medical laboratory-that equipment is there and it } \\
\text { functions. }\end{array}$ \\
\hline \multirow[t]{2}{*}{ Social educator } & $\begin{array}{l}\text { Environment } \\
\text { therapy }\end{array}$ & $\begin{array}{l}\text { The SE is responsible for daily care and social support, and facilitates } \\
\text { and ensures the quality of a patient's well-being and training activities. } \\
\text { The work is related to people with physical disabilities, mental illness, } \\
\text { substance abuse problems, and dementia. }\end{array}$ \\
\hline & Administration & $\begin{array}{l}\text { The SE may be case manager for support contacts and recruits and } \\
\text { follows up with support contacts and manages applications for } \\
\text { individual plans. The SE may be the contact for the coordinating unit } \\
\text { and provides advice and guidance, and assists people with mental and } \\
\text { physical limitations }\end{array}$ \\
\hline
\end{tabular}

Journal of Research in Interprofessional Practice and Education

Vol. 5.2

November 2015 


\section{JRIPE}

7

Shadowing: Interprofessional Learning

Vasset \& Almås

\section{Reflection notes}

The reflective note revealed that the students had different experiences when shadowing the OT and SE in their professional practice. They also saw the value of and need for collaborative practice in home care.

\section{Table 2. Reflection notes}

\begin{tabular}{|c|c|}
\hline Students' experience & Students' statements \\
\hline $\begin{array}{l}\text { Students' experience } \\
\text { shadowing OT }\end{array}$ & $\begin{array}{l}\text { - An OT had more knowledge than I thought they had. } \\
\text { - They can do more than manage with aids, training, and facilitation at } \\
\text { home. She contributes to identifying measures and targets to solve the } \\
\text { user's problems, and she collaborates well with people who are around } \\
\text { this person. } \\
\text { - The OT discovered something that the nurse and I could not see. } \\
\text { - The 0T thinks differently than "us" nurses: whereas we work based on } \\
\text { assumptions that are already present and to bring out the resources of the } \\
\text { patient, the OT is there to see [what] possibilities of the patient can be } \\
\text { exploited using assistance and facilitation. } \\
\text { - When I am a nurse, I think, through seeing how an 0T works, I am going } \\
\text { to have a lower threshold to contact this professional. }\end{array}$ \\
\hline $\begin{array}{l}\text { Students' experience } \\
\text { shadowing SE }\end{array}$ & $\begin{array}{l}\text { - An SE does jobs that are more pedagogical in nature compared with } \\
\text { nurses, and generally they have more time to interact with their users } \\
\text { than nurses do. }\end{array}$ \\
\hline $\begin{array}{l}\text { Students' experience } \\
\text { with a week of } \\
\text { shadowing practice }\end{array}$ & $\begin{array}{l}\text { - It is easier for an upcoming nurse to collaborate with other professions } \\
\text { when one is familiar with them. When I see a patient in need of } \\
\text { interprofessional capability, it is easier for me to see who can be } \\
\text { contacted. } \\
\text { - It was good to see how they worked and how we can work with the } \\
\text { various professions in the best possible way. } \\
\text { - The time for collaborative practice is suitable in home care placement. } \\
\text { Collaboration between professional groups is essential for the patients to } \\
\text { get the holistic care they need and are entitled to. } \\
\text { - Every professional has different knowledge, but together they can form a } \\
\text { good partnership. Every single professional can give their opinions and } \\
\text { ideas, and together find solutions, or multiple solutions, to problems. }\end{array}$ \\
\hline
\end{tabular}

Journal of Research in Interprofessional Practice and Education

Vol. 5.2

November 2015

\section{Focus group interviews}

The students expressed that the shadowing IPL was useful for their future work in health and social care. 
Shadowing: Interprofessional Learning

Vasset \& Almås
Table 3. Focus group interviews

\begin{tabular}{|c|c|}
\hline Categories & Statements \\
\hline $\begin{array}{l}\text { Knowledge about } \\
\text { other healthcare } \\
\text { professionals }\end{array}$ & $\begin{array}{l}\text { - It was a learning period, got more insight or access to other professional work. } \\
\text { - We saw what they did and how they did it. } \\
\text { - Got a lot of information about the profession's responsibilities and what their work } \\
\text { entailed, and we gained insight into other professionals and their everyday competence. }\end{array}$ \\
\hline Collaborative practice & $\begin{array}{l}\text { - We saw the importance of collaboration processes and good communication. } \\
\text { - Seeing how different healthcare professionals met and seeing how they work. } \\
\text { - Integrated care for patients-it is important. } \\
\text { - I saw this [integrated care] in all patient pathways. }\end{array}$ \\
\hline Localization of IPL & - We did not learn in the same way as we had in school. \\
\hline Assessment of IPL & $\begin{array}{l}\text { - It is a pity that not all students [spend] a week doing interprofessional shadowing practice. } \\
\text { - Doing this shadowing was positive learning that I want to continue. } \\
\text { - It does not destroy anything in the practice study. } \\
\text { - It does something to us so that we can act as a good nurse when we are finished. }\end{array}$ \\
\hline
\end{tabular}

\section{Discussion}

The purpose of this study was to examine how nursing students experience interprofessional shadowing practice for a week in municipal healthcare. As previously mentioned the home care service is growing rapidly and involves many professions. White Papers $[3,5,31]$ and previous research $[7,9]$ indicate that the health and social care professions acquire collaborative competence through interprofessional experience. The White Paper Education for Welfare: Interaction as Key [5] underlines that IPL should primarily occur in placements where students in relevant practical situations can acquire knowledge about other professional qualifications. This might minimize prejudice and stereotypes [11], which may lead to better collaborative practice and consequently improve quality in health and social care.

\section{Insight into the professions' responsibilities}

Results from the focus group interviews and templates indicate that students gained insights into the characteristics of the professional practitioners they followed. Orvik [4] highlights the importance of holistic patient care, as in taking a holistic view in relation, for example, to the preparation of individual plans. Nurses were seen to be organizers in healthcare, which is in line with Askjem [32] and Almås [14]. The students said, for example, that the focus of the BMLSs is on quality of analysis and procedure, which also emerged in previous research on BMLS's core competences [14,33,34].

The results show that nursing students perceive that occupational therapy has habilitation and ergonomics as central responsibilities, which appears in the curriculum for OTs [35]. The OT is concerned with reinforcing daily activities for patients/clients with physical or mental problems or social needs [36]. The results also
Vol. 5.2

November 2015
Journal of Research in Practice and Education 
9

Shadowing: Interprofessional Learning

Vasset \& Almås

Journal of Research in Interprofessional Practice and Education

Vol. 5.2 November 2015 show that students learned that the main areas of SE are environmental therapy and administration. This appears in the curriculum, which highlights topics such as environment therapy and managing work [37]. Both occupational therapy and physiotherapy have treatment and rehabilitation functions associated with disease [38]. The research tradition in physiotherapy is marked by traditional natural scientific methodology, while occupational therapy can be said to have a humanistic and qualitative-oriented research tradition. Physiotherapy is related to rehabilitation and training after illness and competence connected to the treatment of physical and psychometrics disorders [38]. The students learned that physiotherapy is related to rehabilitation/habilitation and prevention, which partly coincides with Nordtvedt and Grimen's [38] point of view.

\section{Students' experience of shadowing practice in home care}

During a focus group interview, some students stated that they felt this kind of learning can be advantageously linked to the placement period. The students indicated that they would not have learned the same topics on campus. Previous studies show that shadowing practice enhances students' motivation for collaborative practice $[15,20]$, and, according to Dickinson and Carpenter [10], collaborative competence cannot be acquired through theory alone.

Practice in home care is somewhat different from institutional practice because the practitioners work in the patient's home [1]. White Papers [3,5] indicate that the service should be adapted to the society we live in. People with different complex disorders should have the opportunity to live at home, which can result in a better quality of life [1]. It is very often a nurse who visits the patient and assesses whether he/she needs other professions to alleviate suffering and prevent disease [1]. It can be a PT, OT, SE, and/or BMLS. The results of this study show that students who have knowledge about other professionals' competence felt this task would be easier for them.

Earlier research emphasizes that IPL implies learning and that learning requires reflection-reflection with other professionals or with other students [16] —and IPL provides more occasions for interactions [12]. Based on concrete experience [18,19], reflective conversations would foster the development of practical professional knowledge [17]. During shadowing, the students experienced concrete activities, then they reflected on their observations and what this meant for patient care [13]. Reflective notes showed that the students were particularly concerned about the OT's knowledge and work. It may be that the students had little knowledge of this profession in advance.

Through interprofessional shadowing practice, the students can observe the work environment, work practices, and professional skills of other professions [14]. If students had questions about what characterizes a specific profession, they could ask a professional directly during the shadowing practice.

The result shows that students had positive experiences with shadowing practice in the municipal health service. It is unclear whether it is sufficient to shadow only four professionals because home care involves a number of different types of professionals that nursing students would collaborate with in their future careers. 


\section{Journal of Research in Interprofessional Practice and Education}

Placement in home care during the second year can be an ideal arena and timeframe for IPL. In this context it would be important for students to first become familiar with and confident in their own profession [16]. We can assume that second year students would have some knowledge about their own profession.

\section{Implications for health and social care programs}

Placements in which students take part along with students from other professional programs can be challenging to implement in smaller educational institutions that have few health and social care programs. A week of interprofessional shadowing practice, where students choose relevant professions to follow in their professional practice, may be feasible for small educational institutions that want to implement IPL. A challenge can be the typically large cohorts of nursing students compared with other healthcare programs, such as BLMS.

The results of this study concern nursing students in home care. The project might be transferred as a practical model for both nursing students and students in other health and social professions. The aim was to acquire knowledge about other professions' roles and responsibilities as well as the need for collaborative practice.

Students who were exposed to IPL in their course might be better prepared to collaborate and hence to improve the quality of health and social services. In order for IPL to be implemented appropriately in educational institutions and clinical departments, it must be incorporated in the students' curricula. It is also essential that the managers of educational institutions support such initiatives.

\section{Methodological considerations}

The purpose of this study was to investigate how nurse students experienced interprofessional shadowing practice in home care. Templates, reflective notes, and focus group interviews with 12 nursing students formed the basis for data analysis. The students' positive experience with shadowing IPL emerged from all the different data. This reinforces the validity of the results. Since working in home care has a different character from work in institutions, it is conceivable that this could affect the results. Researchers may, to some extent, affect data collection, analysis, and results [39].

To ensure the anonymity of the informants, the informants were asked not give any other background information to avoid recognition of the respondents.

\section{Ethical considerations}

The Norwegian Social Science Data (NSD) approved this project. We obtained written consent from the students who participated in the focus group interviews and completed the templates and reflective notes.

\section{Further research}

This is a qualitative study; we cannot generalize the findings. The study provides evidence that it may be interesting and important to pursue the main findings through further research, such as quantitative studies and/or qualitative observation studies. 
JRIPE

11

Shadowing: Interprofessional Learning

Vasset \& Almås

Journal of Research in Interprofessional Practice and Education

Vol. 5.2

November 2015

\section{Journal of Research in Interprofessional Practice and Education}

\section{Conclusion}

The Norwegian government's White Paper Coordination Reform [3] was adopted to improve the quality of healthcare, and the White Paper Education for Welfare [5] indicates the importance of IPL to improve student's ability to work across professional boundaries. This study shows that 12 nursing students from the second-year cohort experienced and reflected on other professionals' roles and responsibilities through participation in shadowing IPL. The students acquired knowledge about several professionals and were aware of the need for collaborative practice in home care. This may lead to increased interprofessional collaborative competence, and may thereby improve healthcare quality in the future.

\section{Note}

1. This municipality has employed biomedical laboratory scientists at a medical centre, and is responsible for phlebotomy.

\section{Abbreviations}

Biomedical laboratory scientists BMLS

Centre for the Advancement of Interprofessional Education CAIPE

Interprofessional education IPE

Norwegian Social Science Data NSD

Occupational therapists OT

Physiotherapists PT

Social educators SE

\section{References}

1. Fjørtoft, Ann-Kristin. (2006). Hjemmesykepleie. (Home nursing). Bergen, NO: Fagbokforlaget.

2. Ministry of Health and Welfare. (2005-2006). White Paper No. 25. 2005-2006. Mastery, opportunities and meaning. Oslo, NO: Ministry of Health and Welfare.

3. Ministry of Health and Care Services. (2008-2009). Meld. St. Nr.47. Samhandlingsreformen: Rett behandling - på rett sted - til rett tid [Coordination reform Proper treatment - at the right place and right time. Report no 47 to the Storting]. Oslo, NO: Ministry of Health.

4. Orvik, Arne. (2004). Organisatorisk kompetanse [Organizational competence]. Oslo, NO: Cappelen Akademisk forlag.

5. Ministry of Education and Research. (2012). Meld. St. Nr.13. Utdanning for Velferd. Samspill $i$ Praksis [Education for welfare: Cooperation in practice. Report no 13 to the Storting]. Oslo, NO: Ministry of Education and Research.

6. Ministry for Knowledge. (2008). Government No. 2008. Curriculum for nurses. Oslo, NO: Ministry for Knowledge. https://www.regjeringen.no/globalassets/upload/kd/vedlegg/uh/rammeplaner /helse/rammeplan_sykepleierutdanning_08.pdf

7. Almås, Synnove Hofseth. (2007). Interprofessional education: An analysis of the introduction of a common core in curricula for selected health professions [Thesis]. Bergen, NO: University of Bergen.

8. Centre for the Advancement of Interprofessional Education (CAIPE). (1997). Interprofessional education: A definition. CAIPE Bulletin No. 13. p19. Fareham, UK: CAIPE.

9. Barr, Hugh, Koppel, Ivan, Reeves, Scott, Hammick, Marilyn, \& Freeth, Della. (2005). Effective interprofessional education: Argument, assumption and evidence. Oxford, UK: Blackwell.

10. Dickinson, Claire, \& Carpenter, John. (2005). "Contact is not enough": An inter-group perspective on stereotype change in Inter Professional Education. In Hazel Colyer, Marion Helme \& Isabel Jones (Eds.), The theory-practice relationship in interprofessional education (pp. 23-30). London, UK: Higher Education Academy.

11. Barr, H. (1994b). NVQs and their implications for inter-professional collaboration. In Leathard, A. (Ed.), Going Inter-Professional. London: Routledge. 
12

Shadowing: Interprofessional Learning

Vasset \& Almås

Journal of Research in Interprofessional Practice and Education

Vol. 5.2

November 2015
12. Reeves, Scott, \& Freeth, Della. (2002). The London training ward. An innovative interprofessional learning initiative. Journal of Inter Professional Care, 16(1), 41-5.

13. Kolb, David A. (1984). Experiential Learning: Experience as the Source of Learning and Development. Englewood Cliffs, NJ: Prentice Hall.

14. Almås, Synnove Hofseth. (2011). Biomedical laboratory science students and nursing students in shadowing interprofessional learning: a pilot study. The Biomedical Laboratory Scientist, 9, 14-19.

15. Fougner, Marit, \& Hortvedt, Tone. (2011). Students' reflections on shadowing interprofessional teamwork: A Norwegian case study. Journal of Interprofessional Care, 25(1), 33-38.

16. Clark, Phillip G. (2009). Reflecting on reflection in interprofessional education: Implications for theory and practice. Journal of Inter Professional Care, 23(3), 213-223.

17. Hiim, Hilde. (2010). Pedagogisk aksjonsforskning [Educational action research]. Oslo, NO: Gyldendal Academic.

18. Nilsen, Sigurd Roger, Røysing, Hanne, \& Brynhildsen, Siri. (2012). Experienced, write, share, discuss and learn. Uniped, 35(2), 54-66.

19. Mann, Karen, Gordon, Jill, \& MacLeod, Anna. (2009). Reflection and reflective practice in health professions education: a system review. Advances in Health Sciences Education, 14, 595-621.

20. Lindquist, Susanne, Duncan, Anna, Shepstone, Lee, Watts, Fiona, \& Pearce, Shirley. (2005). Casebased learning in cross-professional groups - the development of a pre-registration interprofessional learning program. Journal of Interprofessional Care, 19(5), 12.

21. Pearson, Pauline, Dickinson, Claire, Steven, Alison, \& Dawson, Pam. (2007). Toward a common goal: Developing practice-based interprofessional education in North East England. In Hugh Barr (Ed.), Piloting interprofessional education (19-55), Occasional Paper No. 8.

22. Risjordet, Mark W., Dunbar, Sandra B., \& Molonay, Margret. (2002). A new foundation for methodological triangulation. Journal of Nursing Scholarship, 23, 269-272.

23. Ødegaard, Atle, \& Bjørkly, Stål. (2012). A mixed method approach to clarify the construct validity of interprofessional collaboration. Journal of Interprofessional Care, 26(4), 283-288.

24. Morse, Janice M., \& Field, Peggy Anne. (1995). Qualitative research methods for health professionals. Thousand Oaks, CA: Sage.

25. Cooper, Helen, Spencer-Dawe, Eileen, \& McLean, Elspeth. (2005). Beginning the process of teamwork: Design, implementation and evaluation of an inter-professional education intervention for first year undergraduate students. Journal of Interprofessional Care, 19(5), 492-508.

26. McMaster University. (2010). Reflections evaluation. McMaster University, ON: Institute of Interprofessional Health Education.

27. Nilsen, Sigurd Roger, Røising, Hanne, \& Brynildsen, Siri. (2010). URL: http://www2.hiof.no/nor /avdeling-for-helse_-og-sosialfag/studier-ved-hs/bachelor-i-sykepleie/praksis_-sykepleie [October, 2015].

28. Halkier, Bente. (2010). Fokusgruppe intervju [Focus Group Interview]. Oslo, NO: Gyldendal Academic.

29. Lindgren, Simon. (2011). Tekst analyse [Text analyses]. In Katrine Fangen \& Ann-Mari Sellerberg I Mange forskjellige metoder [In many different methods]. Oslo, NO: Gyldendal Academic Press.

30. Malterud, Kirsti. (2011). Kvalitative metoder i medisinsk forskning [Qualitative methods in medicinal research]. En innføring. Oslo, NO: Universitetsforlaget.

31. Social and Health Services. (2005). Og bedre skal det bli [And better it will be]. National strategy for quality improvement in health and social services. Oslo, NO: Norwegian Directorate of Health. URL. https://helsedirektoratet.no/publikasjoner/og-bedre-skal-det-bli-nasjonal-strategi-forkvalitetsforbedring-i-sosial-og-helsetjenesten-20052015 [November 16, 2015].

32. Askjem, Solveig. (1996). Helse- og sosialarbeiderens sosiale roller [Health and social workers' professional roles]. Oslo, NO: TANO.

33. Almås, Synnove Hofseth, \& Ødegaard, Atle. (2012). What characterizes biomedical laboratory science core competence? Will it work in the future? The Biomedical Laboratory Scientist, 9, 12-18.

34. Almås, Synnove Hofseth, \& Ødegaard, Atle. (2013). Biomedical laboratory science core competence. A quantitative study. The Biomedical Laboratory Scientist, 6(7), 24-30.

35. Regjeringen.no. (2005). (Government.no). Nasjonal loereplan for ergoterapeut [The national curriculum for occupational therapy education]. Oslo, NO: Ministry of Education. URL: http://www .regjeringen.no/upload/kilde/kd/pla/2006/0002/ddd/pdfv/269372-rammeplan_for _ergoterapeututdanning_05.pdf [January 1, 2009].

36. Quality Assurance Agency for Higher Education. (2001). Benchmark statement: Health care programs. Gloucester, UK. 


\section{JRIPE \\ Journal of Research in Interprofessional Practice and Education}

13

Shadowing: Interprofessional Learning

Vasset \& Almås

37. Regjeringen.no. (2006). (Government.no). Nasjonal læreplan for vernepleier [The National Curriculum for Social Education]. Oslo, NO: Ministry of Education. URL: http://www.regjeringen .no/upload/kilde/kd/pla/2006/0002/ddd/pdfv/269377-rammeplan_for_vernepleierutdanning _05.pdf [January 1, 2009].

38. Nortvedt, Per, \& Grimen, Harald. (2004). Philosophy and science of health care. Oslo, NO: Gyldendal Academic Press.

39. Kvåle, Steinar. (2001). Kvalitative forskningsintervju [The quantitative research interview]. Oslo, NO: Ad Nordam Gyldendal. 